
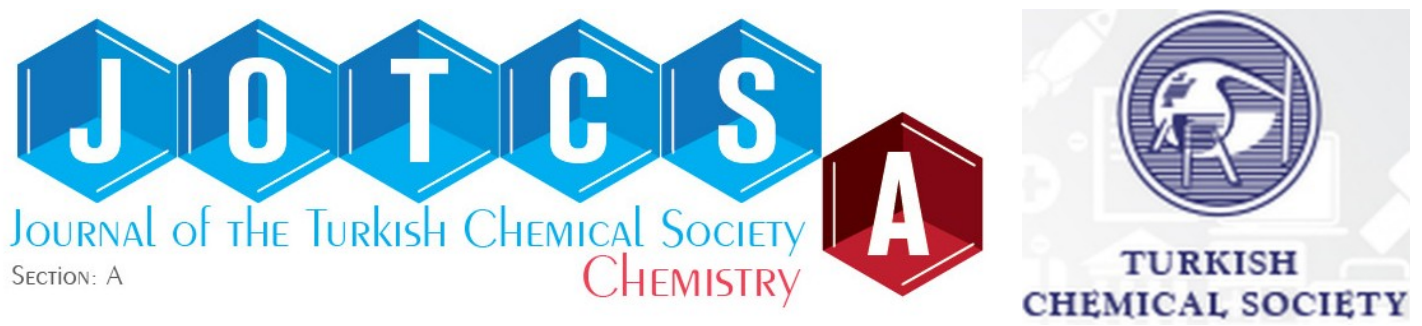

\title{
An Overview of the Polymeric Materials that can be Used to Prevent Metal Corrosion: A Review
}

\author{
Abhishek Dwivedi $^{1 *} \triangle$ iD, Prem Kumar Bharti ${ }^{1} \square$ iD, Sudhish Kumar Shukla $\triangle$ \\ ${ }^{1}$ Integral University, Lucknow, India \\ ${ }^{2}$ Manav Rachna University, Faridabad, India
}

\begin{abstract}
Traditional study has discovered that natural materials such as wood are scarce and that synthetic materials can serve as suitable substitutes. Polymer chemicals, plant materials, chemical compounds, inorganic compounds, and other corrosion inhibitors all use metals. When technology fails, corrosion is one of the most severe consequences, causing harm to the financial system, natural resources, and people's lives. Natural materials such as wood are scarce, according to traditional research, and synthetic materials may serve as suitable replacements. Polymers as corrosion inhibitors have piqued researchers' attention from both a theoretical and practical standpoint. It has been seen from the research that natural polymer inhibitors exhibits more than $90 \%$ efficiency and good surface cover on carbon steel surface. A summary of forms of corrosion, corrosion processes, and recent work on the application of polymer inhibitors on the basis of parameters such as cost, convenience of use, environmental impact, and reliability has been reviewed.
\end{abstract}

Keywords: Corrosion, polymer inhibitor, metal, acids.

Submitted: May 17, 2021. Accepted: July 20, 2021.

Cite this: Dwivedi A, Bharti P, Shukla S. An Overview of the Polymeric Materials that can be Used to Prevent Metal Corrosion: A Review. JOTCSA. 2021;8(3):863-72.

DOI: https://doi.org/10.18596/jotcsa.894374.

*Corresponding author. E-mail: abhishekdwi2003@hotmail.com.

\section{INTRODUCTION}

When surfaces deteriorate due to chemical reactions with their surroundings, then corrosion happens. Rusting can also occur in plastics, concrete, and wood, although it is more prevalent in metals. Corrosion is the formation of more solid products as a result of surface reactions in a chemical or electrochemical reaction as metals or alloys are attacked in their environments such as air, water, or dust. The most commonly used metal is iron (usually steel), and the corrosion of this metal is the subject of the following question. Corrosion is shown by the rusting of iron $\left(\mathrm{Fe}_{2} \mathrm{O}_{3} \cdot \mathrm{H}_{2} \mathrm{O}\right)$ and the forming of a green carbonate film $\left[\left(\mathrm{Cu} \mathrm{CO}_{2}+\mathrm{Cu}(\mathrm{OH})_{2}\right]\right.$ on copper (1-5).

Metals are generated by their ores (oxide, chloride, sulfides etc.) found in Earth's crust by different metallurgical processes.

Table 1: A table showing that most of the materials decay overtime.

\begin{tabular}{lll}
\hline Material & Type of decay & Mitigation actions \\
\hline Wood & Fungi, Insects, and Sun+rain & Chemicals, Paint/varnish \\
Steel & Rust & Galvanizing, Painting \\
Concrete & Cracking / Spalling & Corrosion-resistant rebar \\
Stone & Wear, Damage by Pollution & Usually none taken \\
Glass & Breaks & Tempered glass \\
Polymer & Become brittle under UV light & Improved polymer grades \\
Aluminum & Pitting over time, possible galvanic Galvanic corrosion can be prevented
\end{tabular}


corrosion

Copper Forms a green patina over time Stainless steel No decay

\section{Corrosion Research Explanations}

As per IUPAC, "Corrosion is an irreversible interfacial reaction of a material (metal, ceramic, polymer) with its environment which results in its consumption or dissolution into the material of a component of the environment. Often, but not necessarily, corrosion results in effects detrimental to the usage of the material considered. Exclusively physical or mechanical processes such as melting and evaporation, abrasion or mechanical fracture are not included in the term corrosion"

Corrosion can affect our lives in a variety of ways, from the inconvenience of a seized nut on our vehicles to a disaster caused by a combustion chamber break in a jet plane engine. Understanding corrosion processes aids in product design and selection to ensure high levels of safety. The most important factor in corrosion prevention is safety, but economy is also important (6). Corrosion costs money not only because the object must be removed, but also because time and processing materials are wasted $(7,8)$. Studies also shown that metallic building depreciation has an important impact on the economies of all countries, including roads, transport, accommodation, construction and development, and government. The need for expensive retrofits is eliminated by proper construction. Corrosion management should be considered during the facility's commissioning and service $(9,10)$. Corrosion in buildings and installations can be avoided by applying appropriate inhibitors to water cooling and increasing the distribution of impressed current cathodic safety. In the United States, the cost of corrosion, both direct and indirect, is expected to be about $\$ 279$ billion a year, or 3.2 percent of GDP (GDP). In India, the direct cost of corrosion is projected to be $\$ 26.1$ billion (2.4 percent of GDP) (11-17). Corrosion engineering is the science of preventing and controlling corrosion. Corrosion is estimated to save $\$ 9.3$ billion in costs. The most serious effects of infrastructural defects are the loss of financial wealth, natural resources, and human lives. Metals are commonly used as automotive parts in modern times, which makes them mostly corrupt. Alloys are the only viable option, but not the most strong. Corrosive production is an ordinary phenomenon which transforms a polished metal, such as oxide, hydroxide and sulfide, into a chemically stable state. It decreases the strength, appearance, and fluid and gas permeability of the material and structural properties. It was found to form the studies that the rate of corrosion on mild steel in different conditions like dry, marine, humid (additional to different agents) has been stated as $0.001,0.02,0.2 \mathrm{mmpy}$, respectively.
None

None required

\section{Mechanism of Corrosion}

Corrosion chemistry is complex, but can be divided into an electrochemical phase. An anode during corrosion occurs at a certain point on the surface of an iron material. The electrons formed at this anodic position, when $\mathrm{H}^{+}$is present, flow through the metal in a separate position and reduce oxygen (which is assumed to be accessible from $\mathrm{H}_{2} \mathrm{CO}_{3}$ produced by carbon dioxide dissolution into water in a moist atmosphere). The ion of hydrogen in water is present in order to dissolve other acid oxides in the atmosphere. This place is a cathode used as basic two reactons.

\section{a) Oxidation}

(anodic reaction)

$\mathrm{Fe} \leftrightarrows \mathrm{Fe}^{2+}+2 \mathrm{e}^{-}$

b) Reduction

i) In neutral and alkaline medium

$\mathrm{O}_{2}+2 \mathrm{H}_{2} \mathrm{O}+4 \mathrm{e}^{-} \rightarrow 4 \mathrm{OH}^{-}$

ii) In acidic medium

$2 \mathrm{H}^{+}+2 \mathrm{e}^{-} \rightarrow \mathrm{H}_{2}$

a) Formation of rust

$\mathrm{Fe}^{2+}+2 \mathrm{OH}^{-} \rightarrow \mathrm{Fe}(\mathrm{OH})_{2}----------(4)$

$\mathrm{Fe}(\mathrm{OH})_{2} \rightarrow^{\text {(oxidation) }} \mathrm{Fe}(\mathrm{OH})_{3}$

Rust -- (5)

$\left[\mathrm{Fe}_{2} \mathrm{O}_{3} \cdot \mathrm{H}_{2} \mathrm{O}\right]$

The concept of corrosion must be expanded to include microbially mediated causes based on a better understanding of how different microorganisms in soil and water function. Chemical and electrochemical corrosion, high temperature and low temperature corrosion, wet corrosion and dry corrosion, etc. are all examples of corrosion. $(18-20)$

\section{Two Forms of Corrosion}

When there is no humidity or dampness to aid corrosion, dry corrosion occurs, and the metal oxidizes on its own, whereas metals undergo wet corrosion as a result of electron movement, which includes two measures: oxidation and decrease.

Metal iotas lose electrons during oxidation. The electrons in decrease are then picked up by the surrounding condition. The anode is the metal that lacks electrons. The cathode is the second metal, fluid, or gas that absorbs electrons, while the medium is the electrolyte (21-23).

Micro-corrosion cells are created due to the heterogeneity in metal or in corrosive environment. These cells are classified as Galvanic Cell and Concentration Cell, which represents two dissimilar metals, are immersed in electrolyte / corrosive environment as well as the concentration of the electrolyte is not uniform around the metal respectively. 
The several forms of corrosion have been discussed as Uniform Corrosion, which represents dissolution of iron or zinc piece in acid solution, Galvanic Corrosion in steel pipe connected to copper plumbing, Pitting Corrosion where failure occurs suddenly, Intergranular Corrosion due to localized attack occurs adjacent to grain boundaries, Fretting Corrosion due to mechanical action of solid body on the metal under load and moving condition, Selective Leaching due to removal of one of the element from alloy by corrosion process, Stress Corrosion due to the fact that it occurs in specific corrosive environment and Crevice Corrosion $(8,21,23,24)$.

\section{Inhibitors}

Inhibitors are compounds that are applied to the corrosion medium when corrosion occurs in a damp atmosphere to slow the rate of corrosion by delaying the anodic and/or cathodic processes. A significant part of the cost can be minimized by using inhibitors.

NACE defined inhibitors as "A substance which retards corrosion when added to an environment in appropriate concentration" whereas ISO defined as "A chemical substance which decreases the corrosion rate when present in the corrosion system at a suitable concentration without significantly change in the concentration of any other corrosive agent".

Many of the researchers discussed that a good corrosion inhibitor must act as cost-effective, chemically inert, a good inhibitor of dissolution of metal and environmental friendly as well as, it should not decompose during service condition, and inhibit the diffusion of hydrogen into metal $(6,20,25,26)$.

\section{LITERATURE REVIEW}

One significant pattern in present day human advancement is to impact slow substitution of common materials particularly made of wood through whichever altogether engineered materials otherwise adjusted characteristic resources. The quick industrial development of numerous nations demonstrates the shrinkage in metal assets. Clearly, metals are critical in current building yet many can be severely influenced by corrosion since they are related with high vitality. In the cutting edge age, it is basic to alter the properties of a metal and additionally combinations as per customized particulars intended for target applications. Be that as it may, after the alterations the serious issues related with the metallic materials is its destructive nature. The degree of consumption relies upon the material synthesis and the idea of the earth to which it is uncovered. Loss of economy, regular assets, and human lives includes serious issues of corrosion, due to if there should be an occurrence of infrastructural breakdown. So it is exceptionally imperative to step into new improvements in consumption alleviation. Counteraction of corrosion of materials in destructive condition is a difficult one. Various techniques have traditionally been used to minimize intake, including cathodic safety, progression monitoring, decreasing quality of the metal pollutant, and using surface therapy approaches as well as consolidating suitable composites (27). In any case, corrosion inhibitors have proved to be the most simple and costeffective method of ensuring and preventing acidic media use. Those same inhibitors restrict use and prevent metal corrosion damage to mechanical ships, equipment, and surfaces. Since inorganic and natural inhibitors are poisonous and costly, recent attempts have been made to find ways to guard against corrosion $(28,29)$. Numerous analysts have as of late centred around corrosion avoidance strategies utilizing green inhibitors for mild steel in acidic solution for imitate modern procedures.

Some papers suggested triazines, anilinopropionates, polymers, dyes, drugs, ionic liquids, natural products (plant extract) N-(6methoxyquinolin-4-yl)-pentane-1,4-diamine (MPD), $\mathrm{N}^{\prime}$-(7-chloroquinolin-4-yl)-N,N-diethyl-pentane-1,4diamine (CDPD), thiosemicarbazide, phenyl isothiocyanate, N-phenylhydrazine-1,2dicarbothioamide (PDA) and azorubine dye (AZB), streptomycin, cephalexin, ceftadizime (CZD), and eco-friendly polyaspartic acid (PASP) $(25,30-40)$ as different effective class of corrosion inhibitors on mild steel in $\mathrm{HCl}$ and $\mathrm{H}_{2} \mathrm{SO}_{4}$ solution interface and found the inhibitor efficiency to be about $90 \%$ and more respectively. To increase the counter consumption and scale restriction properties of metal surfaces, an uncovered multi-use bearer of mesoporous titanium dioxide whiskers $\left(\mathrm{TiO}_{2}(\mathrm{w})(41)\right.$ was contrived in epoxy covering and altered by ethylenediamine tetra (methylene phosphonic corrosive) (EDTMPA) and imidazoline, whereas (42) ginger concentrate as consumption inhibitor from normal assets was concentrated to forestall corrosion of mild steel in corrosive media. (43) PASAC3, PASAC 11 and PASAC13 organic corrosion inhibitors were examined for carbon steel in cooling water.

Several researches reviewed the use of polymers $(25,44)$, organic compounds $(34,45-47)$, natural products $(48,49)$ and so on as corrosion inhibitors (50). The combination of carbon (C) and iron (Fe) forms carbon steel which in broad forms are utilized in marine applications, atomic, petroleum product power plants, transport, concoction preparing, development, mining, and metal handling hardware because of its expense and accessibility. Notwithstanding, corrosions are probably going to assault carbon steel in forceful condition, yet in addition in ordinary condition. The majority of the successful inhibitors have an issue concerning 
biocompatibility, biodegradability, bioaccumulation and harmfulness arrangement that is destructive to the ocean-living space. Inhibitors can be divided into four categories to be specific; anodic inhibitors, cathodic inhibitors, blended inhibitors, and unpredictable consumption inhibitors. The assessment of inhibitors type can be portrayed by electrochemical or submersion test by adding recognized measure of inhibitor into arrangements which are ordinarily seawater.

The section put forth will discuss selective polymers having versatile corrosion inhibition properties i.e., same polymer as corrosion inhibitor for different metals and media (51). The major water-soluble polymeric systems discussed are polyacrylic acid, polyacrylamide, polyvinyl alcohol, polyethylene glycol, polyvinyl pyrrolidone, polyethylene imine, polyelectrolytes, polyphosphates, and natural polymers. Rheology alteration, surface sealing, personal hygiene, and oilfield formulation, corrosion inhibitors, polymer flooding, precious metal-ion recovery, and colloid stabilization are only a few of the uses for these water soluble polymers. Some of the synthetic polymers like polyacrylic acid, polyvinyl alcohol, sulfonated polystyrene, etc. $(52,53)$, have extensively been used in medicinal field for drug delivery, implants, medical devices and injectable polymer conjugates. The inhibitor efficiency of N1,N1-diallyl-N6,N6,N6,N5tripropylhexane-1,6-diaminium (NDTHDC), for carbon steel in 15 percent $\mathrm{HCl}$ solution and found that poly-NDTHDC is better than NDTHDC in 1000 $\mathrm{mg} / \mathrm{L}$ inhibitor and was used in weight loss, electrochemical, and surface testing techniques. The efficacy of the inhibition increased but afterwards fell at $60^{\circ} \mathrm{C}$ of the combination (54). There are a few consumption control techniques to alter the materials viable, which incorporates cathodic insurance, $(22,55,56)$; anodic insurance, $(57,58)$ and alloying. The utilization of substance inhibitors, $(59,60)$ was the principle corrosion counteraction method in which change of the earth was considered. This technique is regularly considered as the best and common sense strategy for corrosion avoidance because of its simplicity of use. A few works have been accounted for the consumption restraint of various metals in different destructive conditions. At first consideration was fixated on natural mixes. It was audited (61) that the quantity of announced natural mixes while other papers (62$65)$ has talked about the different heterocyclic mixes utilized as corrosion inhibitors. Worldwide awareness on the natural effect of the natural mixes established the framework for the improvement of earth sympathetic mixes as green inhibitors. Green inhibitors incorporate normal plant materials and non-harmful, eco-benevolent polymers (66-68) in their audit articles secured the distinctive revealed plant materials for consumption hindrance of metals.
Polymers, copolymers, joined polymers, and polymer composites have also become more common as natural antioxidants in recent years (69). $(70,71)$ in their articles investigated the polymers for consumption counteraction applications. The elite of the polymeric consumption inhibitors is because of its bigger size and various utilitarian tying down gatherings. The polymers essentially get adsorbed on the metal surface through the binding down gatherings and ensure slightly additional substrate than that of the corresponding monomers. Polymeric mixtures were tried for their capability to control the corrosion procedure utilizing traditional and electrochemical systems. The adequacy of the inhibitors was assessed using electrochemical techniques such as potentiodynamic polarization, potentiostatic polarization, direct polarization, and electrochemical impedance spectroscopy. Some other extraordinary systems utilized for the assessment of polymeric corrosion inhibitors were talked about in detail. (72) According to some papers, polymer is a good covering medium for plain carbon (soft) steel to prevent corrosion in an acidic medium like hydrochloric acid. At high current thickness, polymerization of the shielding operator frames enormous and circular miniaturized scale particles with a rough surface. Polymerization of the polymer covering at low current thickness, on the other hand, produces a smooth and homogeneous polymer film. To have surface insurance, electropolymerization of a polymer on the exterior of a metal may be used. In $1 \mathrm{M} \mathrm{HCl}$, poly(vinyl liquor cysteine) [PVAC] worked well as a mild steel ingestion inhibitor. In an oxalic corrosive form, ammonium persulfate was used to create a waterdissolvable leading polymer composite poly(vinyl liquor cysteine) (20). Examined polymers which act both as antiscalant and inhibitors and resulted that corrosion happens because of synthetic and electrochemical responses. Creator expressed that the natural mixes adsorb superficially and interface with the surface. Leading polymers and biodegradable polymeric materials may likewise assume imperative job in future to shield materials from decay. (61) Using UV, FTIR, and SEM-EDX to characterize a composite, $(73,74)$ discovered that with an increasing focus on the hindrance proficiency (IE) of chitosan biopolymer, it is able to minimize its intake of copper by $3 \%$ using electrochemical (polarization and impedance) and weight reduction calculations combined with morphology tests. (75) Via a weight reduction technique and a potentiodynamic polarization test, the influence of thiocarbanilide (TCB) corrosion inhibitor behavior of high carbon steel in $1 \mathrm{M}$, $\mathrm{H}_{2} \mathrm{SO}_{4}$, and $\mathrm{HCl}$ corrosive arrangements was investigated. The natural compound worked effectively in corrosive solutions at all focuses with standard TCB restriction mastery, according to the data collected. It was discovered that TCB adheres 
to the Langmuir and Frumkin isotherm models of adsorption.

Polyacrylamide (PACM), prepared by radical polymerization technique using ammonium persulfate (APS) as initiator under nitrogen atmosphere (76) tested polymers act as mixed anodic and cathodic inhibitor in the $1.0 \mathrm{M} \mathrm{HCl} 96 \%$ efficiency at room temperature. Many researchers found that oil and gas industries are most suffering from the problem of corrosion (77). Some of the works investigated that because of oxygen, corrosive enviroments, $\mathrm{CO}_{2}$ and $\mathrm{H}_{2} \mathrm{~S}$ defilement, polymeric corrosion inhibitors for the use at metal surface, to hold consumption rates under control, researchers must use weight measurement, EIS, potentiodynamic, and polarization tests to find effective inhibitors for versatile materials. Polymers, unlike small atom consumption inhibitors, have a wider range of applications and greater film-framing capabilities, which may significantly enhance protective obstruction capabilities. This audit counted the most well-known polymeric structures utilized as consumption inhibitors for various phases of the oil and gas investigation, generation and transportation enterprises. Among corrosion alleviation procedures, the utilization of consumption inhibitors despite everything stays to be one of the most financially reasonable techniques in controlling the corrosion rate since these materials can without much of a stretch be applied through bunch as well as ceaseless medications with least measures of material with the point of limiting incomplete or complete shutdowns in the plants. Be that as it may, when contrasted with little atom inhibitors, polymeric materials are not yet as broadly utilized. Polymers, on the other hand, have a considerable capacity for outperforming the showcase of small particle inhibitors while holding the fixation to a minimum due to the intrinsic advantages of these macromolecules, such as stronger film shaping operators, a few possible attachment focuses, and extremely adaptable depolymerization. Polyamine corrosion inhibitors that have been modified with carboxylic corrosive, heterocyclic moieties, thiols, disulfides, and phosphorus-containing useful gatherings are appropriate for joining on the metal surfaces of different hardware and transmission pipelines that are widely utilized. Polymerization techniques are becoming more and more regulated, different designs, stretched, hyper expanded, dendrimeric, and so on, might be increasingly suitable in tending to the exceptionally destructive media experienced when it comes to the oil and gas industries (78). In this analysis, it is mentioned that the inhibition efficiency increases significantly with the increase of theobromacocoa peel polar extract TCPE content using for the examination of corrosion inhibition efficiency of $0.3 \%$ C mild steel bar, however, $(79,80)$ in a number of violent media, both natural and synthetic polymers have proven useful to resist metal corrosion.

Many researchers found that oil and gas industries are most suffering from the problem of corrosion. It was investigated that the due cause of it may be oxygen, acid stimulation, $\mathrm{CO}_{2}$ and $\mathrm{H}_{2} \mathrm{~S}$ defilement in the environment. It was proposed by the researchers that the versatile nature inhibitors with multi-functionality and better film-forming capabilities like polymeric corrosion inhibitors may be the better solution there. Polymeric corrosion inhibitors have been found one of the market-place solutions for minimizing the rate of corrosion since these chemicals can be easily spread by lot and/or ongoing treatments with limited material volumes in order to prevent partial or complete plant interference. Polymeric materials have been shown to be stronger film-forming agents $(81,82)$, several potential binding sites, are highly stable for derivatives and are likely to exceed the performance of small molecular inhibitors while retaining a low concentration.

\section{Industrial Applications of Corrosion Inhibitors}

- $\quad$ Refinery industries: Film forming long chain amines are used as corrosion inhibitors.

- Power Plants: Nitrites, Chromate, Phosphate, Benzotriazoles are used in cooling water.

- Steel Industry: During pickling of steel organic mixed inhibitors are used.

- Acidification of Oil Well: Thermally stable inhibitors are used. e.g. acetylenic compounds, cinnamaldehydes, quaternary salts, and Mannich bases are used as inhibitors.

- Automobiles: For control of internal corrosion of coolants nitrites, phosphonates, Silicates, benzoates, and mercaptans are used.

- For controlling external corrosion, rust proofing pigments are used.

- $\quad$ Reinforce concrete - Calcium Nitrite, calcium stearate, and tannic acid are used.

\section{DISCUSSION}

The preceding literature provides an outline of various forms of corrosion, the ingestion process, and previous research on the use of natural polymers as mild steel corrosion inhibitors $(83,84)$. According to the preceding discussion, conventional plant eliminates are viable sustainable consumption inhibitors, but polymers seem to be more suitable for use by the steel specimen. In sulfuric or hydrochloric corrosive medium, reduction of weight, with impedance electrochemistry, were mainly used and confirmed by potentiodynamic polarization and surface morphology techniques about corrosion restraint. There is still a lot of untapped potential, especially in the computational visualization of large concentrate divisions on steel specimen. It will really aid in the establishment of specific 
components for corrosion resistance. Work on the investigations of genuine modern emanating to genuine circumstances is constrained. Some corrosion prevention techniques have been suggested, including raising awareness of high corrosion threats and potential savings, dispelling the misconception that there is little that can be done about corrosion, increasing corrosion savings by sound corrosion protection by updating rules, regulations, standards, and management procedures, and staff training and instruction in corrosion prevention.

Additional research into these plant-based materials in other destructive conditions, such as carbon dioxide, sulfur dioxide, and hydrogen sulfide, is required, while polymers such as linear insulated polymer (polyacrylic acid, polyvinyl alcohol, polystyrene).

$(52,53,85)$, cross-linked insulated polymer (anilineformaldehyde derivatives copolymer), and conducting polymers (polyanthranilic acid, sulfonated polyaniline) seem to have a wide range of applications and potential. Frequency experiments for potential approaches should also be carried out in order to revolutionize these traditional mixes and effectively replace the regular synthetic concoctions that are currently used to monitor corrosion using best inhibitor for corrosion with methods such as chemical process, weight loss method, electrochemical, and atomic analysis of surface using microscopy, among others.

\section{ACKNOWLEDGEMENT}

The manuscript communication number provided by the Research and Development Cell, Integral University, Lucknow is: IU/R\&D/2021-MCN0001131

\section{REFERENCES}

1. Asworth V, Booker C, Charlton H, Fairhurst J. a Short Introduction To Corrosion and Its Control Corrosion of Metals and Its Prevention.

Corrosion\&Protection/Bm. 2012;1-9.

2. Evans UR. Corrosion, Causes and prevention: An engineering problem. J Soc Chem Ind [Internet]. 1926 Aug 13;45(33):582-3. URL: http://doi.wiley.com/10.1002/jctb.5000453306

3. Raja PB, Ismail M, Ghoreishiamiri S, Mirza J, Ismail MC, Kakooei S, Rahim AA. Reviews on Corrosion Inhibitors: A Short View. Chemical Engineering Communications. 2016;203(9): 114556. DOI:

https://doi.org/10.1080/00986445.2016.1172485

4. Wranglen G. An introduction to corrosion and protection of metals. Anti-Corrosion Methods Mater. $1972 ; 19(11): 5$.
5. Zarras $P$, Stenger-Smith JD. Corrosion processes and strategies for prevention: An introduction. In: Makhlouf ASH, editor. Handbook of Smart Coatings for Materials Protection. Woodhead Publishing Limited; 2014. p. 3-28. ISBN: 978-0-85709-680-7.

6. Hari kumar, S., Karthikeyan, S., A.Jeeva, P., Sundaramali G. A Review on Corrosion Inhibition of Aluminium with Special Reference to Green Inhibitors. Int J Recent Sci Res Vol. 2012;3(2):617.

7. Hammonds P. An Introduction to Corrosion and its Prevention. Compr Chem Kinet. $1989 ; 28(C): 233-79$.

8. Natarajan KA. Corrosion: Introduction Definitions and Types [Internet]. NPTEL Web Course. 2014. p. 1-9. URL: https://nptel.ac.in/content/storage2/courses/11310 8051/module1/lecture1.pdf

9. Aramide FO. Corrosion Inhibition of AISI / SAE Steel in a Marine Environment. 2009;(15):47-52.

10. Deshpande PP, Jadhav NG, Gelling VJ, Sazou D. Conducting polymers for corrosion protection: A review. J Coatings Technol Res. 2014;11(4):47394.

11. Tsoeunyane MG, Makhatha ME, Arotiba OA. Corrosion Inhibition of Mild Steel by Poly(butylene succinate)-L-histidine Extended with 1,6diisocynatohexane Polymer Composite in $1 \mathrm{M} \mathrm{HCl}$. Int J Corros [Internet]. 2019 Mar 3;2019:1-12. URL:

https://www.hindawi.com/journals/ijc/2019/740640 9/

12. Kruger J. Cost of Metallic Corrosion. In: Uhlig's Corrosion Handbook: Third Edition. Revie RW (Ed) 2011. p. 15-20. ISBN: 978-0-470-08032-0.

13. The Annual Cost of Corrosion to Ohio [Internet]. 2007. URL:

http://www.brown.senate.gov/imo/media/doc/Ohio Corrosion.pdf

14. Bhaskaran R, Bhalla L, Sarin V. Cost of corrosion protection in Indian oil \& petroleum products transmission pipelines - A case study. Int J Appl Bus Econ Res. 2016;14(7):5169-80.

15. Bhaskaran, R, Palaniswamy, N, Rengaswamy, NS. Cost of Corrosion and Corrosion Auditing in Indian Industries. Corros Rev. 2011;27(Supplement):1-35.

16. NACE International. NACE-international Cost of corrosion study unveiled. Mater Perform 2. 2002; (July):20. 
17. Biezma M V, Cristóbal JRS. Methodology to study cost of corrosion. Corros Eng Sci Technol [Internet]. 2005;40(4):344-52. DOI: https://doi.org/10.1179/174327805X75821

18. Shukla SK, Ebenso EE. Corrosion inhibition, adsorption behavior and thermodynamic properties of streptomycin on mild steel in hydrochloric acid medium. Int J Electrochem Sci. 2011;6(8):3277-91.

19. Yi Y, Liu G, Jin Z, Feng D. The use of conducting polyaniline as corrosion inhibitor for mild steel in hydrochloric acid. Int J Electrochem Sci. $2013 ; 8(3): 3540-50$.

20. Subramania A, Sundaram NTK, Priya RS, Muralidharan VS. Polymeric corrosion INHIBITORS An Overview. Bull Electrochem.

2004;20(February):49-58.

21. Elayaperumal K, Raja VS. Forms of Corrosion. In: Revie RW, editor. Corrosion Failures: Theory, Case Studies, and Solutions. 2015. p. 1-26. ISBN: 978-0-470-45564-7.

22. Roberge PR. Handbook of Corrosion Engineering. 2nd ed. United States: The McGrawHill Companies; 2012. 1057 p. ISBN:

9780071750370.

23. Fortana M., Mita M. The Eight forms of corrosion and the corrective measures. 1953; URL: eprints.nmlindia.org/3414/1/137-148.PDF

24. McCafferty E. Introduction to corrosion science [Internet]. Introduction to Corrosion Science. New York: Springer Berlin Heidelberg; 2010. 1-575 p. ISBN: 978-1-4419-0454-6.

25. Umoren SA, Solomon MM. Recent Developments on the Use of Polymers as Corrosion Inhibitors - A Review. Open Mater Sci J. 2014;8:39-54.

26. Revie RW, Uhlig HH. Corrosion and Corrosion Control Handbook [Internet]. 4th ed. Hoboken, NJ, USA: John Wiley \& Sons, Inc. ; 2008. 495 p. URL: http://doi.wiley.com/10.1002/9780470277270

27. Chigondo M, Chigondo F. Recent Natural Corrosion Inhibitors for Mild Steel: An Overview. J Chem [Internet]. 2016;2016:1-7. URL: http://www.hindawi.com/journals/jchem/2016/6208 937/

28. Abdel-Gaber AM, Abd-El-Nabey BA, Sidahmed IM, El-Zayady AM, Saadawy M. Inhibitive action of some plant extracts on the corrosion of steel in acidic media. Corros Sci. 2006;48(9):2765-79.

29. Sastri VS. Types of corrosion inhibitor for managing corrosion in underground pipelines. In: Underground Pipeline Corrosion [Internet]. Sawston,
United Kingdom: Woodhead Publishing Limited; 2014. p. 166-211. DOI: http://dx.doi.org/10.1533/9780857099266.1.166.

30. Shukla SK. Corrosion inhibitive effect of N- ( 6methoxyquinolin-8-yl ) -pentane-1,4-diamine on mild steel / sulphuric acid solution interface. J Mater Environ Sci. 2015;6(6):1779-86.

31. Zeino A, Abdulazeez I, Khaled M, Jawich MW, Obot IB. Mechanistic study of polyaspartic acid (PASP) as eco-friendly corrosion inhibitor on mild steel in $3 \% \mathrm{NaCl}$ aerated solution. J Mol Liq [Internet]. 2018;250:50-62. DOI: http://dx.doi.org/10.1016/j.molliq.2017.11.160.

32. Habibiyan A, Ramezanzadeh B, Mahdavian M, Kasaeian M. Facile size and chemistry-controlled synthesis of mussel-inspired bio-polymers based on Polydopamine Nanospheres: Application as ecofriendly corrosion inhibitors for mild steel against aqueous acidic solution. J Mol Liq [Internet]. 2020;298:111974. DOI: https://doi.org/10.1016/j.molliq.2019.111974.

33. Singh K. AK, Shukla K. SK, Quraishi MA. Ultrasound mediated Green synthesis of Hexa-hydro Triazines. J Mater Environ Sci. 2011;2(4):403-6.

34. Shukla SK, Quraishi MA. 4-Substituted anilinomethylpropionate: New and efficient corrosion inhibitors for mild steel in hydrochloric acid solution. Corros Sci. 2009;51(9):1990-7.

35. Kabanda MM, Shukla SK, Singh AK, Murulana LC, Ebenso EE. Electrochemical and quantum chemical studies on calmagite and fast sulphone black $f$ dyes as corrosion inhibitors for mild steel in hydrochloric medium. Int J Electrochem Sci. $2012 ; 7(9): 8813-31$

36. Salem H, Samir E. Determination of cefotaxime, cefoperazone, ceftazidime and cefadroxil using surface plasmon resonance band of silver nanoparticles. Brazilian J Pharm Sci. 2018;54(3):19.

37. Shukla SK, Murulana LC, Ebenso EE. Inhibitive effect of imidazolium based aprotic ionic liquids on mild steel corrosion in hydrochloric acid medium. Int J Electrochem Sci. 2011;6(9):4286-95.

38. Shukla SK, Ebenso EE. Effect of condensation product of thiosemicarbazide and phenyl isothiocynate on corrosion of mild steel in sulphuric acid medium. Int $\mathrm{J}$ Electrochem Sci. 2012;7(12):12134-45.

39. Singh AK, Shukla SK, Singh M, Quraishi MA. Inhibitive effect of ceftazidime on corrosion of mild steel in hydrochloric acid solution. Mater Chem Phys. $2011 ; 129(1-2): 68-76$. 
40. Chai C, Xu Y, Shi S, Zhao X, Wu Y, Xu Y, et al. Functional polyaspartic acid derivatives as ecofriendly corrosion inhibitors for mild steel in $0.5 \mathrm{M}$ H2SO4 solution. RSC Adv. 2018;8(44):24970-81.

41. Wang C, Wang $\mathrm{H}$, Hu Y, Liu Z, Lv C, Zhu Y, et al. Anti-Corrosive and Scale Inhibiting PolymerBased Functional Coating with Internal and External Regulation of TiO2 Whiskers. Coatings [Internet]. 2018;8(2):29. URL: http://www.mdpi.com/2079$\underline{6412 / 8 / 1 / 29}$.

42. Fidrusli A, Suryanto, Mahmood M. Ginger extract as green corrosion inhibitor of mild steel in hydrochloric acid solution. In: IOP Conference Series: Materials Science and Engineering. IOP Conf. Series: Materials Science and Engineering; 2017. p. 1-6.

43. Harabor I, Nechifor G, Branzoi V, Branzoi F, Carbon I. Investigation of Some Organic Polymers As Corrosion Inhibitors on Carbon Steel in Cooling Water System. UPBSci Bull, Series B. $2016 ; 78(3): 145-60$.

44. Fathima Sabirneeza AA, Geethanjali R, Subhashini S. Polymeric Corrosion Inhibitors for Iron and Its Alloys: A Review. Chem Eng Commun. 2015;202(2):232-44.

45. Aljeaban NA, Goni LKMO, Alharbi BG, Jafar Mazumder MA, Ali SA, Chen T, et al. Polymers Decorated with Functional Motifs for Mitigation of Steel Corrosion: An Overview. Huang J-C, editor. Int J Polym Sci [Internet]. 2020;2020:9512680. DOI: https://doi.org/10.1155/2020/9512680.

46. Sakhri A, Perrin FX, Benaboura A, Aragon E, Lamouri S. Corrosion protection of steel by sulfodoped polyaniline-pigmented coating. Prog Org Coatings [Internet]. $2011 ; 72(3): 473-9$. DOI: http://dx.doi.org/10.1016/j.porgcoat.2011.06.005.

47. Loto RT, Ayozie BU, Loto CA. Electrochemical study of the corrosion inhibition effect of 3cyanophenyl compound on 420 martensitic stainless steel in strong acid media. IOP Conf Ser Mater Sci Eng. 2019;613(1).

48. Quraishi MA, Ahamad I, Singh AK, Shukla SK, Lal B, Singh V. N-(Piperidinomethyl)-3-

[(pyridylidene)amino]isatin: A new and effective acid corrosion inhibitor for mild steel. Mater Chem Phys. 2008;112(3):1035-9.

49. Amin MA, Ei-rehim SSA, El-sherbini EEF, Hazzazi OA, Abbas MN. Polyacrylic acid as a corrosion inhibitor for aluminium in weakly alkaline solutions. Part I : Weight loss, polarization, impedance EFM and EDX studies. Corros Sci [Internet].
2009;51(3):658-67. DOI:

http://dx.doi.org/10.1016/j.corsci.2008.12.008.

50. Ismail A. A review of Green Corrosion Inhibitor for mild steel in seawater. ARPN J Eng Appl Sci [Internet]. 2016 Jul;11(14):8710-4. URL: http://www.arpnjournals.org/jeas/research papers/ rp 2016/jeas 0716 4665.pdf.

51. Kausar A. Corrosion prevention prospects of polymeric nanocomposites: A review. J Plast Film Sheeting [Internet]. 2019 Apr 11;35(2):181-202. URL:

http://journals.sagepub.com/doi/10.1177/8756087 918806027.

52. DWİVDİ A, BHARTI P, SHUKLA S. Surface assimilation and corrosion inhibition characteristic of water soluble Polyvinyl Alcohol on mild steel surface in $0.5 \mathrm{M} \mathrm{HCl}$ solution. J Turkish Chem Soc Sect A Chem [Internet]. 2021 Jan 11;8(1):219-30. URL: https://dergipark.org.tr/en/doi/10.18596/jotcsa.794 721.

53. Dwivedi A, Bharti PK, Shukla SK. Interaction of water soluble polyacrylic acid with mild steel / hydrochloric acid interface. In: International Conference on Contemporary Research in Mechanical Engineering with focus on Materials and Manufacturing [Internet]. Lucknow--India: IOP Conference Series: Materials Science and Engineering; 2018. p. 1-11. URL: https://iopscience.iop.org/article/10.1088/1757899X/404/1/012044.

54. Odewunmi NA, Solomon MM, Umoren SA, Ali $\mathrm{SA}$. Comparative studies of the corrosion inhibition efficacy of a dicationic monomer and its polymer against API X60 steel corrosion in simulated acidizing fluid under static and hydrodynamic conditions. ACS Omega. 2020;5(42):27057-71. DOI: https://doi.org/10.1021/acsomega.0c02345.

55. Shittu MD, Olawale JO, Adeoye MO, Oluwasegun $\mathrm{KM}$, Adebayo KM, Ige OO. Investigation of corrosion resistance of polystyrene as an inhibitor in hydrochloric and tetra-oxo sulphate VI acids. Int J Mater Chem. 2014;4(1):9-13.

56. Desai PS, Kapopara SM. Inhibiting effect of anisidines on corrosion of aluminium in hydrochloric acid. Indian J Chem Technol. 2009;16(6):486-91.

57. Cecchetto L, Delabouglise D, Petit J. On the mechanism of the anodic protection of aluminium alloy AA5182 by emeraldine base coatings Evidences of a galvanic coupling. 2007;52:3485-92.

58. Praveen BM, Venkatesha T V, Naik YA, Prashantha K. Corrosion studies of carbon nanotubes - Zn composite coating. Surface and 
Coatings Technology. 2007;201:5836-42. DOI: https://doi.org/10.1016/j.surfcoat.2006.10.034.

59. Yang F, Li X, Qiu S, Zheng W, Zhao H, Wang L. Water soluble trianiline containing polyurethane (TAPU) as an efficient corrosion inhibitor for mild steel. Int J Electrochem Sci. 2017;12(6):5349-62.

60. Oyama T. Encyclopedia of Polymeric Nanomaterials [Internet]. Kobayashi S, Müllen K, editors. Encyclopedia of Polymeric Nanomaterials. Berlin, Heidelberg: Springer Berlin Heidelberg; 2020. 1-11 p. URL:

http://link.springer.com/10.1007/978-3-64236199-9.

61. Abdul Rahiman AFS, Sethumanickam S. Corrosion inhibition, adsorption and thermodynamic properties of poly(vinyl alcohol-cysteine) in molar HCl. Arab J Chem [Internet]. 2017;10:S3358-66. DOI:

http://dx.doi.org/10.1016/j.arabjc.2014.01.016.

62. Li Z, Zhu A, Yang J. One-Pot Three-Component Mild Synthesis of 2-Aryl-3-(9-alkylcarbazol-3yl)thiazolin-4-ones. J Heterocycl Chem. 2012;49(Scheme 1):1458-61.

63. Metcalf RL. Indigo and Indigo Colorants. Ullmann's Encycl Ind Chem. 2000;13837329:264322. ISBN: 9783527304103.

64. Dos Pereira JDS, Neri JM, Emerenciano DP, De Freitas GRS, Felipe MBMC, De Souza MÂF, et al. Experimental and theoretical analysis of an oxazinoquinoxaline derivative for corrosion inhibition of AISI 1018 steel. Quim Nova. 2018;41(3):243-50.

65. Stanly Jacob K, Parameswaran G. Corrosion inhibition of mild steel in hydrochloric acid solution by Schiff base furoin thiosemicarbazone. Corros Sci [Internet]. 2010;52(1):224-8. URL:

http://dx.doi.org/10.1016/j.corsci.2009.09.007.

66. Antonijevic MM, Petrovic MB. Copper Corrosion Inhibitors . A review. Rev Lit Arts Am [Internet]. 2008;3(1):1-28. URL:

http://www.electrochemsci.org/papers/vol3/301000 1.pdf.

67. Quraishi MA, Shukla SK. Poly(anilineformaldehyde): A new and effective corrosion inhibitor for mild steel in hydrochloric acid. Mater Chem Phys. 2009;113(2-3):685-9. DOI: https://doi.org/10.1016/j.matchemphys.2008.08.02 8.

68. Srimathi M, Rajalakshmi R, Subhashini S. Polyvinyl alcohol-sulphanilic acid water soluble composite as corrosion inhibitor for mild steel in hydrochloric acid medium. Arab J Chem [Internet].
2014;7(5):647-56. DOI: http://dx.doi.org/10.1016/j.arabjc.2010.11.013.

69. Guo J, Yuan S, Jiang W, Lv L, Liang B, Pehkonen SO. Polymers for combating biocorrosion. Front Mater. 2018;5(March).

70. Umoren SA. Polymers as Corrosion Inhibitors for Metals in Different Media - A Review. Open Corros J [Internet]. 2009;2(1):175-88. URL: http://benthamopen.com/ABSTRACT/TOCORRJ-2$\underline{175}$.

71. Arthur DE, Jonathan A, Ameh PO, Anya C. A review on the assessment of polymeric materials used as corrosion inhibitor of metals and alloys. Int J Ind Chem [Internet]. 2013;4(1):2. URL: http://www.industchem.com/content/4/1/2.

72. Alsingery RMD. Polypyrrole as a Perfect Corrosion Inhibitor for Mild Steel in Hydrochloric Acid Solution Cyclic Voltammetry. Int J ChemTech Res. 2017;10(9):1058-65.

73. Oukhrib R, El Ibrahimi B, Bourzi H, El Mouaden K, Jmiai A, El Issami S, et al. Quantum chemical calculations and corrosion inhibition efficiency of biopolymer "chitosan" on copper surface in $3 \% \mathrm{NaCl}$. J Mater Environ Sci. 2017;8(1):195-208.

74. Zhang QH, Hou BS, Li YY, Zhu GY, Liu HF, Zhang GA. Two novel chitosan derivatives as high efficient eco-friendly inhibitors for the corrosion of mild steel in acidic solution. Corros Sci. 2020;164.

75. Loto RT, Loto CA, Joseph O, Olanrewaju G. Adsorption and corrosion inhibition properties of thiocarbanilide on the electrochemical behavior of high carbon steel in dilute acid solutions. Results Phys [Internet]. 2016;6:305-14. DOI: http://dx.doi.org/10.1016/j.rinp.2016.05.013.

76. Azzam EMS, El-Salam HMA, Mohamed RA, Shaban SM, Shokry A. Control the corrosion of mild steel using synthesized polymers based on polyacrylamide. Egypt ] Pet [Internet]. 2018;27(4):897-910. DOI: https://doi.org/10.1016/j.ejpe.2018.01.006.

77. Tiu BDB, Advincula RC. Polymeric corrosion inhibitors for the oil and gas industry: Design principles and mechanism. React Funct Polym [Internet]. 2015;95:25-45. DOI: http://dx.doi.org/10.1016/j.reactfunctpolym.2015.0 8.006.

78. Yetri Y, Emriadi, Jamarun N, Gunawarman. Corrosion Inhibition Efficiency of Mild Steel in Hydrocloric Acid by Adding Theobroma Cacao Peel Extract. International Conference on Biological, Chemical and Environmental Sciences. 2014;15-9. DOI: http://dx.doi.org/10.15242/IICBE.C614002. 
79. Hussain AK, Sudin I, Basheer UM, Yusop MZM. A review on graphene-based polymer composite coatings for the corrosion protection of metals. Corros Rev. 2019;37(4):343-63.

80. Keramatinia M, Ramezanzadeh B, Mahdavian M. Green production of bioactive components from herbal origins through one-pot oxidation/polymerization reactions and application as a corrosion inhibitor for mild steel in $\mathrm{HCl}$ solution. J Taiwan Inst Chem Eng. 2019;105:134-49. DOI: https://doi.org/10.1016/j.jtice.2019.10.005.

81. Rokaya D, Srimaneepong V, Sapkota J, Qin J, Siraleartmukul K, Siriwongrungson V. Polymeric materials and films in dentistry: An overview. J Adv Res [Internet]. 2018;14:25-34. DOI:

https://doi.org/10.1016/j.jare.2018.05.001.

82. Umoren SA, Solomon MM. Protective polymeric films for industrial substrates: A critical review on past and recent applications with conducting polymers and polymer composites/nanocomposites. Prog Mater Sci [Internet]. 2019;104:380-450. DOI: https://doi.org/10.1016/j.pmatsci.2019.04.002.

83. Ismail AS, Farag AA. Experimental, theoretical and simulation studies of extracted crab waste protein as a green polymer inhibitor for carbon steel corrosion in $2 \mathrm{M} \mathrm{H} 3 \mathrm{PO} 4$. Surfaces and Interfaces [Internet]. 2020;19:100483. DOI: https://doi.org/10.1016/j.surfin.2020.100483.

84. Jafar Mazumder MA. Synthesis, characterization and electrochemical analysis of cysteine modified polymers for corrosion inhibition of mild steel in aqueous $1 \mathrm{M} \mathrm{HCl}$. RSC Adv. 2019;9(8):4277-94. DOI: https://doi.org/10.1039/C8RA09833F.

85. Dharmalingam V, Sahayaraj $P$, Amalraj A, Prema A. Poly ( acrylic acid ) and Sodium gluconate as effective corrosion inhibitors for mild steel in chloride environment. International Journal of ChemTech Research. 2017;10(5):630-41. 